\title{
Mutations Affecting Gluconate Catabolism in Escherichia coli. Genetic Mapping of the Locus for the Thermosensitive Gluconokinase
}

\author{
By TOMÁS ISTÚRIZ, * EDUARDO PALMERO AND \\ JUANA VITELLI-FLORES \\ Centro de Biologia Celular y Departamento de Biología Celular, Escuela de Biología, Facultad \\ de Ciencias, Universidad Central de Venezuela, Apartado Postal 21201, Caracas, Venezuela
}

(Received 23 January 1986; revised 2 May 1986)

\begin{abstract}
An Escherichia coli strain unable to use gluconate was isolated by spontaneous curing of $\lambda c 1857 s 7$ xis6 b515 b519, $\lambda c 1857 s 7 \Delta(A-a t t)$ dargI valS lysogens. Two lesions, linked to asd and pyr $B$ markers, respectively, were necessary to produce this phenotype. The asd-linked mutation gnt-17, of regulatory type, seems to affect the expression of the major system of gluconate utilization ( $\min 75$ ) as well as that of 6-phosphogluconate dehydratase (gene edd, min 41), the first enzyme of the Entner-Doudoroff pathway. A closely linked suppressor of gnt-17 causes constitutivity of these activities; this suppressor resembles gnt $R$, which is also in the asd region. Hence, it is possible that $g n t-17$ is a super-repressing allele of $g n t R$, rather than a positive controlling element. Lesion gnt-17 alone does not prevent the utilization of gluconate; for this, the mutation gnt-18 at $96.9 \mathrm{~min}$ is also necessary. This mutation abolishes the thermosensitive gluconokinase activity and thus eliminates the subsidiary ability to catabolize gluconate. Accordingly, gnt- 18 seems to be allelic with $g n t V$, the locus postulated as being in the $p y r B$ region specifying the thermosensitive gluconokinase.
\end{abstract}

\section{INTRODUCTION}

The initial steps of gluconate metabolism in Escherichia coli are its entry into the cell and its subsequent phosphorylation to 6-phosphogluconate (Cohen, 1951). 6-Phosphogluconate is catabolized primarily by the Entner-Doudoroff pathway, but also by the pentose phosphate pathway (Eisenberg \& Dobrogosz, 1967; Fig. 1). The two enzymes of the Entner-Doudoroff pathway, 6-phosphogluconate dehydratase (EC 4.2.1.12) and 6-phospho-2-dehydrogluconate aldolase (EC 4.1.2.14), convert 6-phosphogluconate to pyruvate and glyceraldehyde 3phosphate. The dehydratase as well as the gluconate uptake and gluconokinase activity is induced when the cells grow on gluconate (Cohen, 1951; Fraenkel \& Levisohn, 1967; Nagel de Zwaig et al., 1973; Pouysségur et al., 1974); the aldolase is partially constitutive and possibly induced by its substrate (Fradkin \& Fraenkel, 1971).

The induction in normal $E$. coli strains of two transport activities and two gluconokinases has been reported (Hung et al., 1970). In both cases, the carriers and the enzymes displayed different $K_{\mathrm{m}}$ values for gluconate. Later genetic and physiological studies (Nagel de Zwaig et al., 1973; Faik \& Kornberg, 1973; Zwaig et al., 1973) indicated that presumptive structural genes for highaffinity transport ( $g n t T a$ or usgA; here denoted as gnt $T$, see Terminology), low-affinity transport ( $g n t T b$; here denoted as $g n t U)$, gluconate phosphorylation $(g n t K)$ as well as a regulatory gene gnt $R$, were located at the bioH-malA-glpRD-asd region of the chromosome, about min 75 of the map; moreover, it was shown that, while gnt $T$ maps between bio $H$ and malA markers, gnt $U$, $g n t K$ and $g n t R$ map in the asd region (Nagel de Zwaig et al., 1973). Apparently the product of the gnt $R$ gene negatively controls the expression of these activities as well as that of 6phosphogluconate dehydratase, coded by the edd gene at min 41 (Peyru \& Fraenkel, 1968).

Abbreviations: BTB, bromothymol blue; KU, Klett units. 


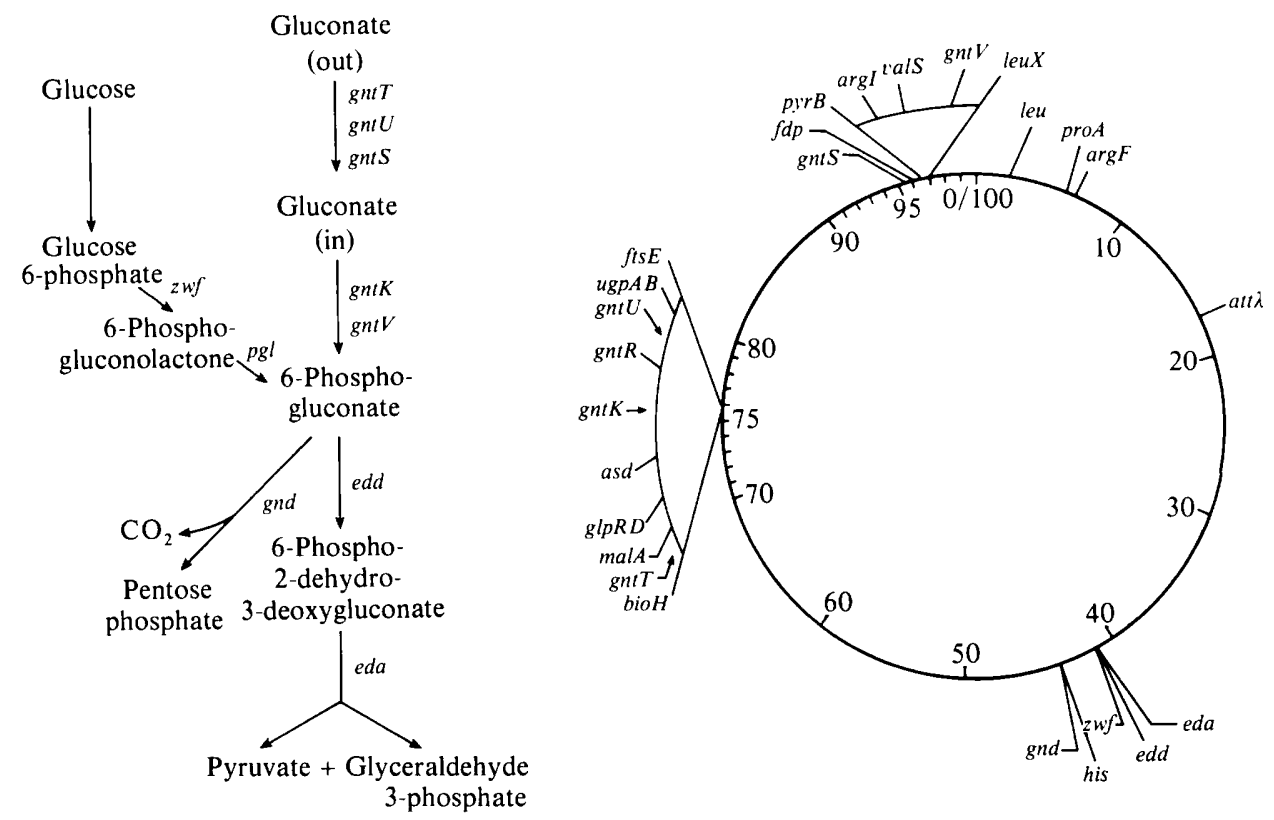

Fig. 1. Catabolism of gluconate in $E$. coli and the location of relevant markers on its linkage map. Arrows indicate the probable sites for $g n t T$, gnt $K$ and $g n t U$ (Nagel de Zwaig $e t$ al., 1973). Location of gnt $V$ according to the present paper. For gluconate symbols, see Terminology. Other symbols according to Bachmann (1983).

The two reported gluconokinases were differentiated in vitro by their heat sensitivities. The thermoresistant one (activity stable for $3 \mathrm{~h}$ at $30^{\circ} \mathrm{C}$ ) mapped in the $75.5 \mathrm{~min}$ region (hence designated $g n t K r$; here denoted gnt $K$ ). The other, thermosensitive one, lost $75 \%$ or more of its activity in those conditions; moreover, a mutation abolishing its activity, probably by altering its structural gene designated gntKs (here denoted gntV), mapped at the pyrB region, min 96.5 (Zighelboim \& Nagel de Zwaig, 1973; R. Nagel de Zwaig and co-workers, unpublished results).

It was suggested that the $75 \mathrm{~min}$ region governed the main gluconate utilization pathway. Phenotypes affected in its expression were designated $\mathrm{GntM}^{-}$; the residual growth in a $\mathrm{GntM}^{-}$ mutant (linkage to malA) was abolished by a second mutation ( $g n t S)$ in the $95.3 \mathrm{~min}$ region ( $33 \%$ linkage to $f d p$ ) suggested as specifying the uptake system of a subsidiary system also involved in transport and phosphorylation of gluconate. Mutant phenotypes of gntS were designated $\mathrm{GntS}^{-}$ (Bächi \& Kornberg, 1975).

Because $E$. coli bioH-asd deleted mutants do not grow in mineral medium with gluconate (Nagel de Zwaig et al., 1973), the above findings suggested that in the absence of this region, the putative subsidiary system of gluconate utilization might not be expressed. In favour of this hypothesis, the isolation in mineral medium with gluconate of spontaneous fermenting pseudorevertants from mutant $\mathrm{HfrG} 6 \Delta \mathrm{MD} 2[\Delta($ bioH-asd $)]$ was reported (Istúriz et al., 1979). One representative pseudorevertant, mutant $\mathrm{C} 177$, constitutively expressed $(\Delta g h t R)$ the dehydratase $(e d d)$ and formed, when grown in media with gluconate, both a high-affinity transport for this substrate and the thermosensitive gluconokinase. The isolation of a different bioH-asd deleted mutant (strain M119), able to grow on mineral medium with gluconate but still unable to ferment this sugar on indicator plates, has also been reported (Wecksler-Albo \& Vitelli-Flores, 1979). Mutant M119, as strain C177 (above), inducibly expressed the activities of the subsidiary system and was constitutive for the dehydratase. To explain its phenotype, it was assumed that the activity of some genetic element of the gluconate system, not included in the deletion (for example, $g n t U$ ) might favour the induction of the subsidiary system. It was additionally shown that strain M119 (on indicator plates with gluconate) gives spontaneously 
fermenting colonies which were constitutive just for the activities inducibly expressed in their parent. The lesion responsible for this constitutivity as well as for that involved in the positive phenotype of strain $\mathrm{C} 177$ were $65 \%$ and $76 \%$, respectively, linked to $\mathrm{pyr} B$.

The present paper offers elaboration and support for the model of two gluconate utilization systems in $E$. coli.

\section{METHODS}

Most of the media and methods have been described (Nagel de Zwaig et al., 1973). Gluconate bromthymol blue indicator plates (BTB-gluconate) contained, per litre: $2.5 \mathrm{~g}$ Bacto peptone, $1.5 \mathrm{~g}$ yeast extract, $10 \mathrm{~g}$ calcium carbonate, $50 \mathrm{mg}$ bromthymol blue, $15 \mathrm{~g}$ agar and $10 \mathrm{~g}$ potassium gluconate. Sugars were added to mineral media at $0.4 \%$.

Organisms. Bacterial strains used are listed in Table 1.

Terminology. The genetic markers (Table 1) are those listed by Bachmann (1983). In reference to the symbols concerned with the initial gluconate catabolism, we have tried, preserving the symbol gnt, to rationalize them according to Demerec et al. (1966). The gene previously denoted as gntTa (Zwaig et al., 1973) or usg A (Faik \& Kornberg, 1973) is written as gnt $T$. The gnt Tb locus specifying the low-affinity transport for gluconate (Zwaig $e t$ al., 1973) and the $g n t K r$ gene coding the thermoresistant gluconokinase are written as $g n t U$ and $g n t K$, respectively. Together, the products of the above-mentioned three genes constitute the main system GntM of gluconate utilization suggested by Bächi \& Kornberg (1975). The locus $g n t K s$, postulated as specifying the thermosensitive gluconokinase (Zighelboim \& Nagel de Zwaig, 1973), is written as gntV. The product of this gene and that of gntS (the subsidiary gluconate uptake activity; Bächi \& Kornberg, 1975) compose the subsidiary system GntS of gluconate utilization. Because GntM and GntS have been used to denote phenotypes concerned with sets of genes (above) and the same symbols with the lower-case $g$ have been utilized as specific genotypic designations (Bächi \& Kornberg, 1975; Bachmann, 1983), we suggest the use of GntI (instead of GntM) and GntII (instead of GntS) as symbols for phenotypes concerned with the main and subsidiary systems respectively. In this context, the symbol gntM (Bachmann, 1983) does not seem suitable to denote transport and phosphorylation of gluconate at min 75 , since this region includes three genes $(g n t T, g n t K$ and $g n t U)$ involved in these activities (Zwaig et al., 1973).

Growth of bacteria. Cells were grown aerobically at $37^{\circ} \mathrm{C}$ in volumes of $15 \mathrm{ml}$ in $125 \mathrm{ml}$ flasks fitted with side arms, on a gyratory water bath shaker (model G76, New Brunswick) at about 200 cycles $\mathrm{min}^{-1}$. For anaerobiosis, cultures were inoculated into standing capped tubes with similar diameters to Klett tubes, filled to capacity with the respective medium and sealed. In each case, the growth was monitored by reading the optical density in a Klett colorimeter with a no. 42 filter.

To determine the effect of pyruvate on the expression of the initial activities of gluconate catabolism, $200 \mathrm{ml}$ of late-exponential-phase cells growing on mineral medium with $0.4 \%$ fructose were centrifuged (3000 r.p.m., SS34 Sorvall) and resuspended in $20 \mathrm{ml}$ mineral medium. Samples were inoculated into $700 \mathrm{ml}$ volumes, contained in 4 litre flasks of the same medium with $0.4 \%$ gluconate, to give $6-7 \times 10^{7}$ cells ml ${ }^{-1}$ (approximately $30 \mathrm{Klett}$ units $\mathrm{KU})$. The cultures were grown aerobically at $37^{\circ} \mathrm{C}$ to $60 \mathrm{KU}$ and divided in two. Pyruvate $(10 \mathrm{~mm})$ was then added to one-half portions of each culture and the incubations were continued for a further generation. Samples of the cells thus grown were harvested for assays of both $\left[\mathrm{U} \cdot{ }^{14} \mathrm{C}\right]$ gluconate uptake and activity of gluconokinase (Fig. 2).

Enzyme assays. Gluconokinase and 6-phosphogluconate dehydratase were assayed by the procedure of Fraenkel \& Horecker (1964). The gluconokinase heat inactivation is reported in each case as the percentage of the gluconokinase activity lost as determined in $0.2 \mathrm{ml}$ volumes of cell extract incubated at $30^{\circ} \mathrm{C}$ for $3 \mathrm{~h}$ and compared to that of the same extract without treatment. Activities are reported as $\mathrm{nmol} \mathrm{\textrm {min } ^ { - 1 } ( \mathrm { mg } \text { protein) }}{ }^{-1}$.

Assay of $\left[U^{-14} \mathrm{C}\right.$ gluconate uptake. Washed cells were suspended in $0.1 \mathrm{M}-\mathrm{Tris} / \mathrm{HCl}$ buffer $(\mathrm{pH} 7.5)$ at a concentration of $3 \times 10^{8}$ cells ml ${ }^{-1}$. Approximately $10^{7}$ cells were incubated with $2 \times 10^{-5} \mathrm{M}-\left[\mathrm{U}-{ }^{14} \mathrm{C}\right]$ gluconate (specific activity $5.6 \mathrm{mCi}(0.21 \mathrm{GBq}) \mathrm{mmol}^{-1} ; 300 \mu \mathrm{l}$ final volume) in the presence of chloramphenicol $\left(50 \mu \mathrm{g} \mathrm{ml}^{-1}\right.$ final concentration) at $30^{\circ} \mathrm{C}$ for $1 \mathrm{~min}$. The cells were collected on a membrane filter $(0.45 \mu \mathrm{m}$ pore size; Millipore $)$ and washed with suction with $15 \mathrm{ml}$ of the same buffer. The filter was dried in a scintillation vial to which $2 \mathrm{ml}$ scintillation fluid $(4 \mathrm{~g}$ PPO and $0.05 \mathrm{~g}$ PPOP per litre of toluene) was added. The concentration of [U${ }^{14} \mathrm{C}$ ]gluconate, $2 \times 10^{-5} \mathrm{M}$, is the approximate $K_{\mathrm{m}}$ value of the high-affinity transport system for gluconate (Nagel de Zwaig et al., 1973). The specific rates of gluconate uptake are expressed as c.p.m. taken up by $10^{7}$ cells $\mathrm{min}^{-1}$. The radioactivity was counted in an automatic scintillation spectrometer (model 3385, Packard Tri-Carb.).

Phages and specialized transductions. The preparation of $\lambda$ phage lysates and specialized transductions were done according to Kikuchi et al. (1975). A stock of P1Kc phage kept in our laboratory was used for generalized transductions; P1Kc lysates were prepared according to Miller (1972).

Selection of $E$. coli mutants affected in gluconate catabolism. To isolate $E$. coli mutants with lesions at the pyrB region which might be affected in gluconate catabolism, strain CA16 (AD9 lysogen carrying the helper $\lambda c 1857 s 7$ xis $6 b 515 b 519$ at the met $A$ region, $\min 91 ; \mathrm{F}$. Santos \& T. Istúriz, unpublished results) was transduced to $\mathrm{Arg}^{+}$with a $\lambda$ lysate obtained from strain $\mathrm{AD} 12 \mathrm{yK} 5$, a $\lambda$ lysogen carrying both the helper prophage and an 

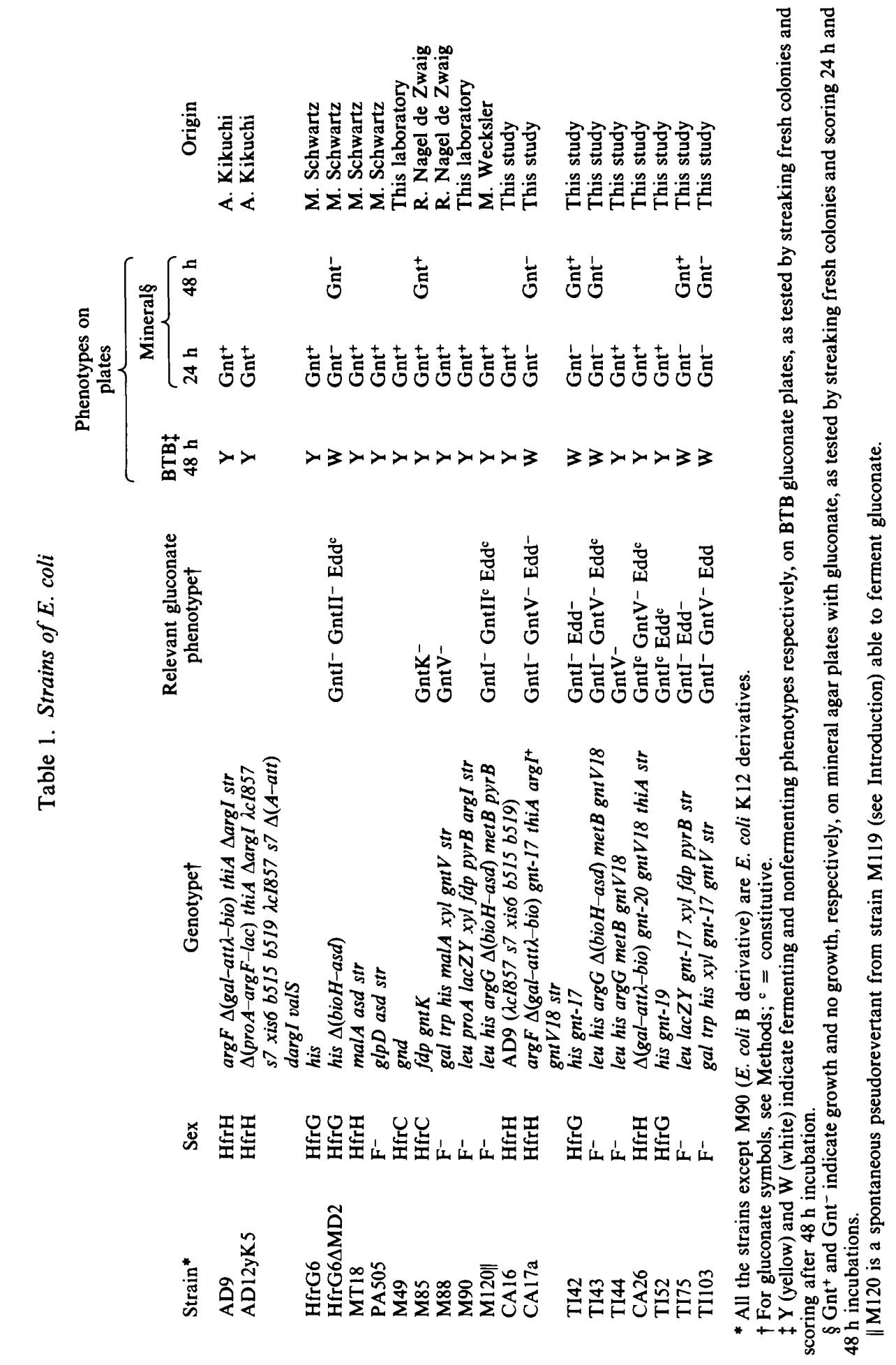
argI valS transducing prophage. Because of the att deletions present on both genomes, the transducing phage and the recipient strain, we expected that some $\operatorname{argI} I^{+}$transductants might have integrated the transducing prophage at the argI-valS region of the recipient chromosome. The subsequent spontaneous curing of such lysogens might produce survivors with lesions at this region which, in the case of those affecting gluconate metabolism, might be detected on indicator plates with gluconate. The transduction frequency was $2 \times 10^{-6}$. Groups of 70 of these transductants were mixed in tubes containing $2 \mathrm{ml} \mathrm{LB}$ broth, cultivated overnight at $30^{\circ} \mathrm{C}$ and screened for cured cells by plating volumes of $0.2 \mathrm{ml}$, appropriately diluted, on $\mathrm{LB}$ plates at $42^{\circ} \mathrm{C}$. The spontaneous curing frequency (survival at $42^{\circ} \mathrm{C} /$ survival at $30^{\circ} \mathrm{C}$ ), determined according to Shimada et al. (1972), was $1.6 \times 10^{-5}$. Of these colonies, 117 out of 120 were $\mathrm{ArgI}^{+}$; unexpectedly, three of them were neither able to grow on mineral agar plates with gluconate nor to ferment this sugar on indicator plates. The study of one of these mutants, designated strain CA17a, is reported here. Supporting the idea that the above three colonies arose by curing of $\lambda$ lysogens with prophages inserted into (or near) gluconate genes, was the finding that two out of 200 independent $\mathrm{Arg}^{+}$lysogens investigated displayed a gluconate phenotype similar to that of strain CA17a. These two lysogens, not considered in detail in this paper, gave (by spontaneous curing) survivors which kept the gluconate phenotype of the parents.

Chemicals. Sodium [U-14 C ]gluconate, specific activity $5.6 \mathrm{mCi}(0.21 \mathrm{GBq}) \mathrm{mmol}^{-1}$, was obtained from Amersham. D-Gluconic acid (potassium salt), 6-phosphogluconic acid (trisodium salt), lactic dehydrogenase, pyrimidine nucleotides and most other chemicals were purchased from Sigma. Culture media were obtained from Difco.

\section{RESULTS AND DISCUSSION \\ Characteristics of mutant $\mathrm{CA17a}$}

This mutant grew normally at $37^{\circ} \mathrm{C}$ on mineral medium supplemented with glucose, maltose, fructose or glycerol but not with gluconate; other sugars were not tested. Table 2 shows that it lacked both gluconokinase and 6-phosphogluconate dehydratase and was substantially affected in its inducible capacity to take up gluconate. Colonies of strain CA17a were white on BTBgluconate plates; however, it was possible to detect on such plates yellow fermenting colonies which arose spontaneously and always showed constitutive activities of the gluconate system. One representative pseudorevertant, mutant $\mathrm{CA} 26$, was constitutive for a high-affinity transport, the thermoresistant gluconokinase and the dehydratase (Table 2). Since phenotypes like that shown by mutant CA26 arise from mutations in just the gnt $R$ gene (min 75.5 ; Zwaig et al., 1973; Bächi \& Kornberg, 1975), the location of the suppressor mutation (gnt-20) in mutant CA26 of the CA17a phenotype was directly investigated in the malA-asd region. When gluconate mutant $\mathrm{HfrG} 6 \triangle \mathrm{MD} 2$ was transduced to asd $^{+}$with phage $\mathrm{P} 1$ grown in strain CA26, all the transductants $(56 / 56)$ resulted in yellow colonies on BTB-gluconate plates; eight independent transductants investigated were constitutive for gluconate activities. These results suggested that the gnt-20 mutation might be allelic with gnt $R$. One possibility was that the highaffinity uptake systems induced in mutant CA17a and derepressed in strain CA26 were different and differently regulated, e.g. that in mutant CA17a perhaps specified by gntS and that in mutant CA26 coded by gnt $T$, as tested below.

\section{Mapping of lesions affecting the gluconate system in mutant CA17a}

Since mutations in the pyrB region $(96.5 \mathrm{~min})$ are not sufficient to prevent growth on gluconate (unpublished results), we thought that mutant CA17a might be affected both in this region (considering its origin as an $\mathrm{ArgI}^{+}$transductant of an $\arg F \operatorname{argI}$ strain) and, additionally, in the bioH-asd region ( $75 \mathrm{~min})$. To examine this possibility, mating experiments using this mutant as donor and strains PA505 and M90 as recipients were performed, and the $\mathrm{Gnt}^{-}$ phenotype (see Table 1) of the recombinants was investigated (Table 3). Among the PA505 recombinants, as scored after $24 \mathrm{~h}$ incubation, the $\mathrm{Gnt}^{-}$phenotype was most closely linked $(55 \%)$ to asd; but with a further $24 \mathrm{~h}$ incubation most $\mathrm{Gnt}^{-}$recombinants grew sufficiently to be then scored as $\mathrm{Gnt}^{+}$on mineral plates with gluconate [although they still appeared as mutants (white) on BTB-gluconate indicator plates]. In the case of M90 recombinants, those which were $\mathrm{Gnt}^{-}$on mineral plates at $48 \mathrm{~h}$ always contained the $\operatorname{pyr} B$ allele from the donor (data not shown). Despite the effect that the operating restriction in $\mathbf{K} \times \mathbf{B}$ crosses could have in the recombination frequencies detected (Boyer, 1964), this result, together with that of strain 


\section{Table 2. Activities of gluconate catabolism}

Cells were cultivated on mineral medium with the indicated carbon source at $0.4 \%$ and collected during the exponential phase, then grown on $1 \%$ casein hydrolysate with $0.4 \%$ of the indicated carbon source up to $200 \mathrm{KU}$. For units, see Methods. HfrG6 was used as control.

\begin{tabular}{|c|c|c|c|c|}
\hline Strain & $\begin{array}{l}\text { Carbon } \\
\text { source }\end{array}$ & $\begin{array}{c}{\left[\mathrm{U}-{ }^{14} \mathrm{C}\right] \text { Gluconate }} \\
\text { uptake }\end{array}$ & Gluconokinase* & $\begin{array}{r}\text { 6-Phosphoglu } \\
\text { dehydrat }\end{array}$ \\
\hline HfrG6 & $\begin{array}{l}\text { Fructose } \\
\text { Gluconate }\end{array}$ & $\begin{array}{r}25 \\
1925\end{array}$ & $\stackrel{4}{472}(24 \%)$ & $\begin{array}{r}2 \\
197\end{array}$ \\
\hline HfrG6 $\Delta \mathrm{MD} 2$ & $\begin{array}{l}\text { Fructose } \\
\text { Gluconate }\end{array}$ & $\begin{array}{l}12 \\
18\end{array}$ & $\begin{array}{r}\text { ND } \\
6\end{array}$ & $\begin{array}{l}280 \\
310\end{array}$ \\
\hline M120 & $\begin{array}{l}\text { Fructose } \\
\text { Gluconate }\end{array}$ & $\begin{array}{l}373 \\
416\end{array}$ & $\begin{array}{r}67(86 \%) \\
127(90 \%)\end{array}$ & $\begin{array}{r}161 \\
36\end{array}$ \\
\hline CA17a† & $\begin{array}{l}\text { Fructose } \\
\text { Gluconate }\end{array}$ & $\begin{array}{r}41 \\
398\end{array}$ & $\begin{array}{l}2 \\
3\end{array}$ & $\begin{array}{r}3 \\
10\end{array}$ \\
\hline TI42 & $\begin{array}{l}\text { Fructose } \\
\text { Gluconate }\end{array}$ & $\begin{array}{r}48 \\
414\end{array}$ & $\begin{array}{l}7 \\
39(83 \%)\end{array}$ & $\begin{array}{l}5 \\
4\end{array}$ \\
\hline TI43† & $\begin{array}{l}\text { Fructose } \\
\text { Gluconate }\end{array}$ & $\begin{array}{l}350 \\
405\end{array}$ & $\begin{array}{l}\text { ND } \\
\text { ND }\end{array}$ & $\begin{array}{c}346 \\
\mathrm{NI}\end{array}$ \\
\hline TI44 & $\begin{array}{l}\text { Fructose } \\
\text { Gluconate }\end{array}$ & $\begin{array}{r}53 \\
1256\end{array}$ & $\begin{array}{l}\text { ND } \\
216(9 \%)\end{array}$ & $\begin{array}{l}\text { ND } \\
99\end{array}$ \\
\hline CA26 & $\begin{array}{l}\text { Fructose } \\
\text { Gluconate }\end{array}$ & $\begin{array}{r}1018 \\
792\end{array}$ & $\begin{array}{l}275(0 \%) \\
123(0 \%)\end{array}$ & $\begin{array}{l}181 \\
132\end{array}$ \\
\hline TI52 & $\begin{array}{l}\text { Fructose } \\
\text { Gluconate }\end{array}$ & $\begin{array}{r}1200 \\
911\end{array}$ & $\begin{array}{l}741(0 \%) \\
742(0 \%)\end{array}$ & $\begin{array}{l}343 \\
400\end{array}$ \\
\hline
\end{tabular}

ND, Not detected; NI, not investigated.

* Percentages in parentheses indicate gluconokinase lability (percentage lost after $30^{\circ} \mathrm{C}$ preincubation; see Methods).

$\dagger$ Cultivated only on mineral medium with $0.4 \%$ fructose and then grown as indicated above.

Table 3. Mapping of lesions in mutant CAI7a by conjugation The matings were interrupted at $120 \mathrm{~min}$.

\begin{tabular}{|c|c|c|c|c|c|}
\hline \multirow[b]{3}{*}{ Donor/recipient } & \multirow[b]{3}{*}{$\begin{array}{l}\text { Selected } \\
\text { markers }\end{array}$} & \multirow[b]{3}{*}{$\begin{array}{l}\text { No. } \\
\text { scored }\end{array}$} & \multicolumn{3}{|c|}{ Unselected markers $(\%)$} \\
\hline & & & & \multicolumn{2}{|c|}{$\mathrm{Gnt}^{-*}$} \\
\hline & & & pyr $B^{+}$ & $24 \mathrm{~h}$ & $48 \mathrm{~h}$ \\
\hline CA17a/PA505 & $\begin{array}{l}\text { asd } d^{+} \text {str } \\
\text { glpD } D^{+} \text {str }\end{array}$ & $\begin{array}{r}107 \\
78\end{array}$ & & $\begin{array}{l}55 \cdot 1 \\
29 \cdot 4\end{array}$ & $\begin{array}{l}2 \cdot 8 \\
0 \cdot 0\end{array}$ \\
\hline $\mathrm{CA} 17 \mathrm{a} / \mathrm{M} 90$ & $\begin{array}{l}\text { proA } A^{+} \text {str } \\
\text { leu } u^{+} \text {str } \\
\text { fdp }^{+} \text {str } \\
\text { pyrB } B^{+} \text {str }\end{array}$ & $\begin{array}{r}96 \\
112 \\
92 \\
112\end{array}$ & $\begin{array}{c}16 \cdot 6 \\
28 \cdot 5 \\
\text { NI }\end{array}$ & $\begin{array}{l}2 \cdot 0 \\
0 \cdot 8 \\
2 \cdot 1 \\
0 \cdot 0\end{array}$ & $\begin{array}{l}1 \cdot 0 \\
0 \cdot 0 \\
2 \cdot 1 \\
0.0\end{array}$ \\
\hline
\end{tabular}

NI, Not investigated.

* Numbers indicate percentages of recombinants which did not grow on mineral plates with gluconate as tested by streaking and scoring after $24 \mathrm{~h}$ and $48 \mathrm{~h}$ incubation.

PA505, supported the idea that mutant CA17a carried two lesions affecting gluconate metabolism, one in the $g l p D$-asd region and another in the $p y r B$ region, with inheritance of both needed for complete incapacity to use gluconate.

To locate the lesions more precisely, several $\mathrm{P} 1$ transductions were performed using CA17a as donor. Among the asd $^{+}$transductants obtained when strains PA505 and HfrG6 1 MD2 were recipients, $73 \%(60 / 82)$ and $100 \%(62 / 62)$ respectively, gave white nonfermenting colonies on BTB-gluconate, but they grew $\left(\mathrm{Gnt}^{+}\right)$on gluconate mineral plates in $48 \mathrm{~h}$. Furthermore, with 
Table 4. Transductional analysis of lesions at pyrB affecting gluconate catabolism

\begin{tabular}{|c|c|c|c|c|c|c|c|c|c|}
\hline \multirow[b]{2}{*}{ Donor/recipient } & \multirow{2}{*}{$\begin{array}{c}\text { Selected } \\
\text { marker }\end{array}$} & \multirow{2}{*}{$\begin{array}{l}\text { No. } \\
\text { scored }\end{array}$} & \multicolumn{7}{|c|}{ Unselected markers $(\%)$} \\
\hline & & & $f d p^{+}$ & $p y r B^{+}$ & gnt-18 & $f d p^{+} g n t-18$ & fdp $g n t-18$ & $p y r B^{+} g n t-18$ & pyrB gnt-18 \\
\hline \multirow[t]{2}{*}{ CA17a/TI75 } & pyr $B^{+}$ & 128 & $53 \cdot 1$ & & $45 \cdot 3$ & $23 \cdot 3$ & 21.8 & & \\
\hline & $f d p^{+}$ & 101 & & 49.5 & $15 \cdot 8$ & & & 15.8 & 0.0 \\
\hline \multirow[b]{2}{*}{ TI103/TI75 } & & & $f d p^{+}$ & pyr $B^{+}$ & gnt $V$ & $f d p^{+} g n t V$ & fdp gntV & pyr $B^{+}$gntV & pyrB gntV \\
\hline & $\begin{array}{l}\text { pyr } B^{+} \\
\text {fdp }\end{array}$ & $\begin{array}{l}145 \\
127\end{array}$ & 48.9 & & $\begin{array}{l}44 \cdot 8 \\
17 \cdot 3\end{array}$ & $21 \cdot 3$ & 23.4 & $15 \cdot 7$ & 1.5 \\
\hline
\end{tabular}

Table 5. Transductional analysis of lesions at asd affecting gluconate catabolism

The nonfermenting (gnt-17) and constitutive (gnt-19) phenotypes were identified on TTZ-gluconate plates as indicated in the text.

\begin{tabular}{|c|c|c|c|c|c|c|c|c|c|c|}
\hline \multirow{2}{*}{$\begin{array}{l}\text { Donor/ } \\
\text { recipient }\end{array}$} & \multirow{2}{*}{$\begin{array}{c}\text { Selected } \\
\text { marker }\end{array}$} & \multirow{2}{*}{$\begin{array}{l}\text { No. } \\
\text { scored }\end{array}$} & \multicolumn{8}{|c|}{ Unselected markers ( $\%)$} \\
\hline & & & $\mathrm{malA}^{+}$ & $a s d^{+}$ & gnt -17 & gnt -19 & $a s d^{+}$gnt-17 & asd gnt-17 & $\mathrm{malA}^{+} \mathrm{gnt}-17$ & malA gnt -17 \\
\hline TI42/MT18 & $\mathrm{malA}^{+}$ & 48 & & $56 \cdot 2$ & $33 \cdot 3$ & & $33 \cdot 3$ & $0 \cdot 0$ & & \\
\hline & $a s d^{+}$ & 48 & $62 \cdot 5$ & & $79 \cdot 1$ & & & & $47 \cdot 9$ & $31 \cdot 2$ \\
\hline TI42/M88* & $\mathrm{malA}^{+}$ & 113 & & & $31 \cdot 8$ & & & & & \\
\hline TI52/M88† & $\mathrm{malA}^{+}$ & 292 & & & $0 \cdot 3$ & $34 \cdot 2$ & & & & \\
\hline
\end{tabular}

strain M88 (malA gntV) as recipient, $31 \%(28 / 89)$ of the mal $^{+}$transductants were $\mathrm{Gnt}^{-}$on gluconate mineral plates in $48 \mathrm{~h}$. Thus, in the presence of $g n t V$ in the $p y r B$ region, a mutation (here designated gnt-17) linked to asd in CA17a caused complete incapacity to use gluconate. On the other hand, when a gnt-17 pyrB recombinant $\left(\mathrm{Gnt}^{-} 24 \mathrm{~h}, \mathrm{Gnt}^{+} 48 \mathrm{~h}\right)$ from the conjugation $\mathrm{CA} 17 \mathrm{a} \times \mathrm{M} 90$ (above) was used, $47 \%(42 / 90)$ of the $p y r B^{+}$transductants were $\mathrm{Gnt}^{-}$in $48 \mathrm{~h}$. The lesion involved, linked to $p y r B$ in $C A 17 \mathrm{a}$ and causing complete incapacity to utilize gluconate in the presence of $g n t-17$, was designated gnt-18.

To determine more precisely the location of the gnt- 18 mutation, the same lysate of phage P1 grown on CA17a was used to transduce a gnt-17 pyrB fdp recombinant (strain TI75). The order fdp-pyrB-gnt-18 (Table 4) revealed by such three-factor mapping, and the cotransduction frequencies shown by mutation gnt- 18 with both $f d p$ and $p y r B$ markers, allowed us to locate $(\mathrm{Wu}$, 1966) the investigated lesion at about min 96.9, i.e. between val $S$ and $l e u X$ (see Fig. 1). This region was reported by Kikuchi et al. (1975) as containing the integration site for the $\lambda$ parent prophage in lysogens which originated the argI-valS transducing phage used here to transduce strain CA16 to $\operatorname{argI}^{+}$(see Methods). Because this transducing phage ( $A$ argI valS att int xis6 cIS R;A gene and the att region partially deleted) carries about $0.4 \mathrm{~min}$ of the $E$. coli chromosome in its left arm which does not include the $p y r B$ gene, it is possible to assume, as was expected, that its integration and subsequent excision in the val $S-l e u X$ region of the $E$. coli genome could have caused the gnt-18 lesion.

\section{Study of lesions affecting the gluconate system in mutant CA17a}

One of the recombinants ( $g n t-17 \mathrm{bioH}^{+} \mathrm{malA}^{+} \mathrm{glpD^{+ }}$ asd $d^{+}$) from the P1(CA17a) $\times$ HfrG6 $\triangle \mathrm{MD} 2$ transduction, designated strain TI42, was chosen to characterize the gnt-17 mutation of CA17a. This strain, like all the recombinants assayed from the above transduction, showed white nonfermenting colonies on BTB-gluconate plates but grew slowly on mineral plates with gluconate $\left(\mathrm{Gnt}^{-} 24 \mathrm{~h}, \mathrm{Gnt}^{+} 48 \mathrm{~h}\right)$. The lesion at $75 \mathrm{~min}$ in strain TI42 was confirmed by transduction of strain M88 (mal A gnt V) to mal $^{+} ; 31.8 \%$ of the transductants were $\mathrm{Gnt}^{-}$in 48 $\mathrm{h}$ (Table 5). To investigate the gnt-18 lesion of CA17a, strain M120 [ $\Delta\left(\right.$ bioH-asd) $\left.g n t S^{\mathrm{c}} g n t V^{\mathrm{c}}\right]$ 
Table 6. Doubling times (min) of strains of E. coli

\begin{tabular}{|c|c|c|c|c|}
\hline \multirow[b]{3}{*}{ Strain } & \multicolumn{4}{|c|}{ Carbon source*: } \\
\hline & \multicolumn{2}{|c|}{ Glucose } & \multicolumn{2}{|c|}{ Gluconate } \\
\hline & Aerobiosis & Anaerobiosis & Aerobiosis & Anaerobiosis \\
\hline HfrG6 (wild-type) & 63 & 132 & 94 & 152 \\
\hline CA17a (gnt-17 gnt-18) & 88 & 150 & NG & NG \\
\hline TI42 (gnt-17) & 78 & 128 & 158 & NG \\
\hline TI43 [ $\Delta($ bioH-asd $) g n t-18]$ & 144 & 190 & NG & NG \\
\hline TI44 (gnt-18) & 78 & 157 & 134 & 196 \\
\hline TI52 (gnt-19) & 85 & 135 & 92 & 164 \\
\hline
\end{tabular}

was first transduced to $p y r B^{+}$from CA17a and a $\mathrm{Gnt}^{-}(48 \mathrm{~h})$ recombinant TI43 was then transduced to asd $^{+}$with phage P1 grown on strain HfrG6; strain TI44 was a bioH $\mathrm{HalA}^{+}$asd $\mathrm{m}^{+}$ transductant carrying the gnt-18 mutation and gave 'wild-type' (yellow) phenotype on BTBgluconate indicator plates. The lesion at pyrB in strains TI43 and TI44 was confirmed by transduction of the former strain to $\mathrm{malA}^{+}$asd $^{+}$from CA17a. All the transductants investigated (48/48) were $\mathrm{Gnt}^{-}$in $48 \mathrm{~h}$.

Strains TI42 and TI44 grew normally on mineral medium with glucose under both aerobic and anaerobic conditions. When cultivated in this medium with gluconate, although both strains grew aerobically, only the mutant TI 44 grew also anaerobically, although with a generation time slightly longer than the HfrG6 control (Table 6). Additionally, the levels of [U-14C]gluconate uptake and gluconokinase activity of mutant TI42 were lower than those in mutant TI44; furthermore, mutant TI42 did not express 6-phosphogluconate dehydratase, even when grown on mineral medium with gluconate (Table 2). These results and the fact that the gluconokinases in TI42 and TI44 were the thermosensitive (83\% heat inactivated) and the thermoresistant $(9 \%$ heat inactivated) ones, respectively, suggested that the two strains were using different activities to catabolize gluconate. Indeed, when strain TI42 was transduced to $\mathrm{His}^{+}$with phage P1 grown on strain M49 (gnd edd ${ }^{+}$), approximately $50 \%$ of the $\mathrm{His}^{+}$transductants tested were gnd and $\mathrm{Gnt}^{-}$in $48 \mathrm{~h}$, showing that growth on gluconate in this strain (lacking 6-phosphogluconate dehydratase) depended on 6-phosphogluconate dehydrogenase $\left(\mathrm{gnd}^{+}\right)$. Furthermore, the failure to grow on gluconate anaerobically when only 6-phosphogluconate dehydrogenase is available confirms an earlier report (Fraenkel \& Vinopal, 1973).

We also investigated the effect of pyruvate on the expression of initial activities of gluconate catabolism in strains TI42 and TI44 growing on gluconate. The rationale of this approach was based on the report (Bächi \& Kornberg, 1975) that the two initial systems for gluconate catabolism respond differently to the presence of pyruvate, or any carbohydrate catabolized via this metabolite, in the growth medium. Fig. 2 shows that pyruvate had a marked effect on gluconokinase and gluconate uptake in strain TI42 but not in strain TI44.

Mutant TI43, carrying the gnt-18 mutation as well as having a bioH-asd deletion, lacked gluconokinase activity and remained as its parent strain M120 constitutive for both the subsidiary high-affinity transport for gluconate and the 6-phosphogluconate dehydratase (Table 2). Since the unique gluconokinase activity detected in strain $M 120$ is the thermosensitive one, these results pointed to the gnt-18 lesion as being allelic with $g n t V$, the locus postulated to be at the pyrB region (Zighelboim \& Nagel de Zwaig, 1973) specifying the thermosensitive gluconokinase activity. In support of this hypothesis, a three-factor mapping of $g n t V$ from strain TI103, a Gnt ${ }^{-}(48 \mathrm{~h})$ recombinant $($ gnt-17 gnt $)$ from the transduction P1(CA17a) $\times$ M88, gave the order $f d p-p y r B-g n t V$ (Table 4); moreover, the gntV marker was similar to gnt-18 in its linkage to $f d p$ and $p y r B$, respectively. 


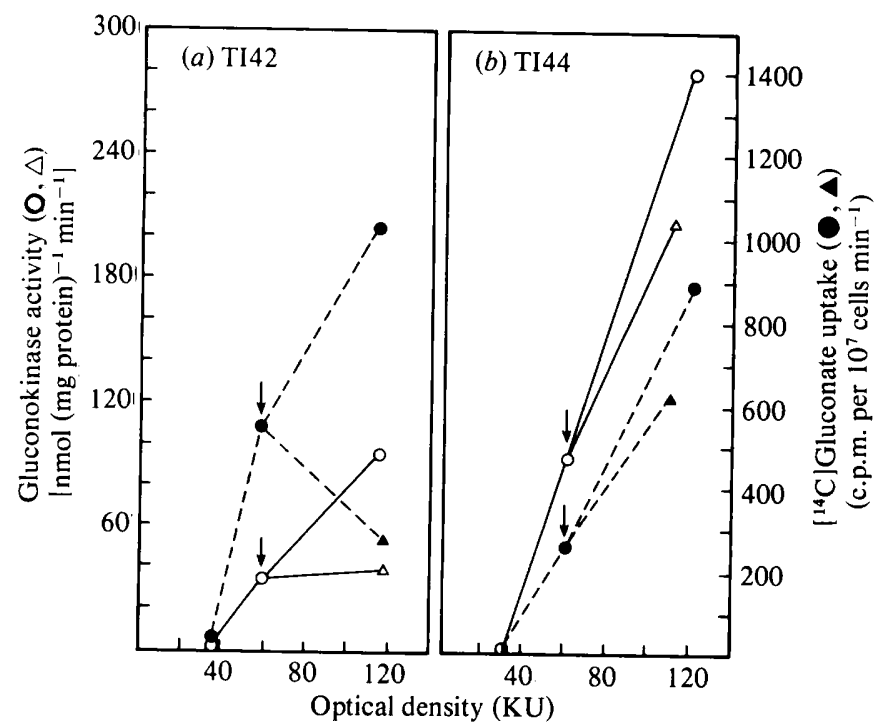

Fig. 2 Effect of pyruvate on the expression of initial activities of gluconate catabolism in strains TI42 $(a)$ and TI44 (b). Gluconate uptake $(O, \Delta)$ and gluconokinase activity $(O, \triangle)$ in the absence $(O, O)$ or presence $(\boldsymbol{\Lambda}, \triangle)$ of pyruvate from cultures grown as indicated in Methods are shown. The arrows indicate when the pyruvate was added.

Two separate but closely linked regions of the $E$. coli map have so far been involved in the subsidiary ability of this bacterium to utilize gluconate (interestingly, two separate but closely linked regions, near $75 \mathrm{~min}$, govern the main system also). The work of Bächi \& Kornberg (1975) pointed to the $95.3 \mathrm{~min}$ region as containing the locus responsible for the subsidiary activity of gluconate uptake. The results presented in this communication reveal the 96.9 min region as being involved in the expression of another subsidiary activity: the thermosensitive gluconokinase.

\section{Pseudorevertants from mutant TI42}

Strain TI42 gave mainly white, nonfermenting colonies on BTB-gluconate plates, but as with the double mutant CA17a, it was always possible to detect a few yellow, fermenting colonies which arose spontaneously. Twenty independent colonies of this type were investigated, and all of them constitutively expressed the activities of gluconate metabolism, as shown in Table 2 for the representative pseudorevertant TI52. Furthermore, strain TI52, unlike its parent TI42, grew on gluconate mineral medium under anaerobic conditions. Under aerobiosis it showed a shorter period of latency $(0.5 \mathrm{~h}$ vs $3 \mathrm{~h}$, data not shown) and a shorter generation time ( $92 \mathrm{~min}$ vs $150 \mathrm{~min}$ ) than strain TI42 (Table 6). The gluconate mutation in strain TI42 (gnt-17), as shown above, was in the $75.5 \mathrm{~min}$ region of the chromosome, and transductional three-factor crosses with respect to mal $A$ and asd markers gave the order malA-asd-gnt-17 (Table 5).

Because a known locus for gluconate constitutivity, gnt $R$, is also in the asd region (Zwaig et al., 1973), a three-factor mapping was also done with TI52 as donor to find out whether the pseudoreversion mutation in TI52 (gnt-19) might be allelic with $g n t R$. The recipient was strain MT18; by contrast with the mapping with TI42, only a small fraction of the transductants $(1 / 318$ and 1/491 among the mal $^{+}$and $a s d^{+}$transductants, respectively) inherited the gnt-17 marker (as tested on tetrazolium indicator plates with gluconate), indicating high linkage between the gnt-17 marker and its suppressor as if this might indeed be $g n t R$.

The same lysate was also used to transduce strain M88 (malA gntV). Scoring was done on tetrazolium gluconate plates (as well as on mineral plates), since gnt $V$ gives pink colonies, $g n t R$ white colonies and gnt-17 red colonies. The $31.8 \%$ linkage of gnt-17 and malA in TI42 was 
replaced by $34.2 \%$ linkage with $g n t-19$ in $\mathrm{TI} 52$, and gnt-17 was recovered at a very low frequency $(0.3 \%$, Table 5). These results also fit with the very close linkage of gnt-17 and gnt-19.

As shown above, the gnt-17 mutation seems to affect the major determinants of gluconate catabolism, the GntI system: high-affinity uptake, thermostable gluconokinase and the expression of 6-phosphogluconate dehydratase (gene edd). Although it seemed reasonable to speculate that $g n t-17$ might affect a positive control element, its suppression by a mutation ( $g$ ntt$19)$ resembling $g n t R$ and the close linkage of $g n t-17$ to $g n t R$ lead us to wonder instead whether it might be a super-repressing allele of gnt $R$. Studies with merodiploids will help to answer this question.

It is not obvious how thermoinduction of $\lambda c 1857 \mathrm{argI}$ vals lysogens resulted in survivors affected at two separate loci. The possibility that the lysogen from which CA17a derived had prophages at those two positions has been supported by the preliminary study of one $\mathrm{Gnt}^{-}(48 \mathrm{~h})$, nonfermenting $\lambda$ lysogen (see Methods). This lysogen, strain TI65, and colonies cured from it lacked gluconate activities. One representative cured colony studied, strain TF2, carried lesions linked to pyr $B$ and asd markers, respectively, just as for mutant CA17a reported here (F. Santos \& T. Istúriz, unpublished). The question therefore arises as to whether physiological 'homology' in gluconate pathways for the 75.5 and $96.5 \mathrm{~min}$ regions might not also reflect nucleic acid homology, allowing the $\operatorname{argI}$ phage to integrate at both positions.

We thank A. Kikuchi for generously providing us with strains, D. G. Fraenkel for his helpful comments and critical reading of the manuscript, and $O$. Valbuena and $A$. Herrera for their help in the revision of the manuscript. This work was supported by the Consejo de Desarrollo Científico y Humanístico de la Universidad Central de Venezuela (Grants C-03.42/82 and C-03.6/85).

\section{REFERENCES}

BÄCHI, B. \& KORNBERG, H. L. (1975). Genes involved in the uptake and catabolism of gluconate by Escherichia coli. Journal of General Microbiology 90 , 321-335.

BaCHMANN, B. J. (1983). Linkage map of Escherichia coli K12, edition 7. Microbiological Reviews 47, 180230.

BOYER, B. (1964). Genetic control of restriction and modification in Escherichia coli. Journal of Bacteriology 88, 1652-1660.

CoHEN, S. S. (1951). Gluconokinase and the oxidative path of glucose-6-phosphate utilization. Journal of Biological Chemistry 189, 617-628.

Demerec, M., Adelberg, E. A., Clark, A. J. \& HaRTMan, P. E. (1966). A proposal for a uniform nomenclature in bacterial genetics. Genetics 54, 6176.

EISENBERG, R. C. \& Dobrogosz, W. J. (1967). Gluconate metabolism in Escherichia coli. Journal of Bacteriology 93, 941-949.

FAIK, P. \& KORNBERG, H. L. (1973). Isolation and properties of $E$. coli mutants affected in gluconate uptake. FEBS Letters 32, 260-264.

FradkIN, J. E. \& FraenKel, D. G. (1971). 2-Keto-3deoxygluconate 6-phosphate aldolase mutants of Escherichia coli. Journal of Bacteriology 108, 12771283.

Fraenkel, D. G. \& Horecker, B. L. (1964). Pathways of D-glucose metabolism in Salmonella typhimurium. Journal of Biological Chemistry 239, 2765-2771.

Fraenkel, D. G. \& Levisohn, S. R. (1967). Glucose and gluconate metabolism in an Escherichia coli mutant lacking phosphoglucose isomerase. Journal of Bacteriology 93, 1571-1578.
Fraenkel, D. G. \& Vinopal, R. T. (1973). Carbohydrate metabolism in bacteria. Annual Review of Microbiology 27, 69-110.

Hung, A., Orozco, A. \& Zwaig, N. (1970). Evidence for two gluconokinase activities in Escherichia coli. Bacteriological Proceedings Abstract, p. 148.

Istúriz, T., Vitelli-FLORES, J. \& MARDENI, J. (1979). El metabolismo del gluconato en $E$. coli. Estudio de una mutante delecionada en la región bioH-asd del mapa cromosómico. Acta científica venezolana $\mathbf{3 0}$, 391-395.

Kikuchi, A., Elseviers, D. \& Gorini, L. (1975). Isolation and characterization of lambda transducing bacteriophages for $\arg F$, arg $I$ and adjacent genes. Journal of Bacteriology 122, 727-742.

MilleR, J. H. (1972). Experiments in Molecular Genetics. Cold Spring Harbor, New York: Cold Spring Harbor Laboratory.

NAGEL DE ZWAIG, R., ZWAIG, N., Istúriz, T. \& SANCHEZ, R. S. (1973). Mutations affecting gluconate metabolism in Escherichia coli. Journal of Bacteriology 114, 463-468.

Peyru, G. \& Fraenkel, D. G. (1968). Genetic mapping of loci for glucose-6-phosphate dehydrogenase, gluconate-6-phosphate dehydrogenase, and gluconate-6-phosphate dehydrase in Escherichia coli. Journal of Bacteriology 95, 1272-1278.

Pouysségur, J. M., FAIK, P. \& Kornberg, H. L. (1974). Utilization of gluconate by Escherichia coli. Uptake of D-gluconate by a mutant impaired in gluconate kinase activity and by membrane vesicles derived therefrom. Biochemical Journal 140, 193203.

Shimada, K., WeisberG, R. A. \& Gottesman, M. E. 
(1972). Prophage lambda at unusual chromosomal locations. I. Location of the secondary attachment sites and the properties of the lysogens. Journal of Molecular Biology 63, 483-503.

WeCKSLER-Albo, M. \& Vitelli-Flores, J. (1979). El sistema metabólico del gluconato en Escherichia coli. Obtención, estudio fisiológico y genético de nuevas cepas con mutaciones que afectan el sistema. Acta cientifica venezolana 30, 484-490.

WU, T. T. (1966). A model for three-point analysis of random general transduction. Genetics 54, 405-410.
Zighelboim, S. \& Nagel de Zwaig, R. (1973). Mapeo genético de una mutación que afecta una gluconoquinasa en Escherichia coli K12. Acta cientifica venezolana 24, Suplemento 1, p. 45.

ZWAIG, N., NAGEL DE ZWAIG, R., IstúrIZ, T. \& WECKSLER, M. (1973). Regulatory mutations affecting the gluconate system in Escherichia coli. Journal of Bacteriology 114, 469-473. 